\title{
THE IMPACT OF BIG DATA ANALYTICS ON IMPROVING FINANCIAL REPORTING QUALITY
}

\author{
Nagat Mohamed Marie Younis \\ Assistant Professor of Accounting, Faculty of Business, Department of Accounting, \\ University of Jeddah, Saudi Arabia, \\ Email:nmarie@uj.edu.sa
}

\begin{abstract}
The current study aims to clarify the importance of big data analytics and its role in changing the accounting profession and the roles of accountants, in addition to testing the impact of big data analytics on improving financial reporting quality in the Saudi environment. To achieve the study's goals and validate hypotheses, relevant previous literature and research are referred. Also, a field study is conducted by distributing a questionnaire of (154) individual academics, financial analysts, accountants, and experts in the field of analyzing big data in the Kingdom of Saudi in 2019. Data are analyzed by using the program of Statistical Package for Social Science (SPSS 17.0). The study concluded that although business organizations face several challenges when analyzing data, big data analytics has a significant role in achieving high competitiveness for institutions, improving the accounting information quality, providing appropriate information that helps in rationalizing decisions within the economic unit, and providing future information affecting stakeholder's decisions. The study also has proved that there is a statistically significant effect of big data analytics on improving the quality of accounting information, as big data analytics clearly affects the characteristics of the accounting information quality, positively affecting the quality of financial reports. The researcher recommends the necessity of teaching big data and business analyses in accounting education curricula at universities to promote students' knowledge. The researcher also recommends holding workshops and training courses for researchers and academics to know the importance of analyzing big data and how to process, store, manage and use the analyzed data in the financial and accounting field. In conclusion, this research is an open intellectual invitation for conducting further applied and scientific research in the field of big data and its impact on accounting and the development of accounting standards.
\end{abstract}

Keywords: Big Data, Big Data Analytics, Accounting Information Qualitative Characteristics, Accounting Information Quality, Accounting Profession, Financial Reporting Quality.

\section{Introduction}

Currently, the world is witnessing what is called "the fourth industrial revolution" led by big data resulting from technological development and automation. The value of this data appears when it is converted to information, big data experts stated that the amount of data will be growing rapidly in the future, in its Data Age 2025 report for Seagate, IDC forecasts the global data sphere will reach $175 \mathrm{ZB}$ by 2025 compared to $4.4 \mathrm{ZB}$ in 2013. In the same report, IDC estimates that 6 billion users or $75 \%$ of the world's population will be interacting with online 
data per day by 2025 (Khvoynitskaya, 2020). And with an increasing volume of data, companies have two options, either ignore this data or benefit from it to achieve competitiveness. However, this is not done with traditional tools. The study of (Al-Aklabi, 2017) has indicated that big data includes many types of data from which can be benefited such as images, and audio and video clips. Consequently, companies have no choice but to acquire data analytics tools to convert data into added value. According to (Krahel et al., 2015), previously, companies have been suffering from a decrease of data and information, but now huge amounts of big data are available from many sources which increase the value and skill of accountants and accounting profession. Thus, companies are in dire need of benefiting from such data and developing the criteria of accounting and auditing with a focus on data analytics to improve accounting information, to raise the efficiency of capital markets, and to help officials and investors in making accurate decisions.

The study of (Coyne, 2018) has analyzed the role of accountants in the era of big data. Although big data has become clearer for accounting, but accountants have little understanding of turning such data into useful information. As a result, there has been a gap between what accountants can and should do to help in big data governance. Therefore, accountants had to play a key role in managing and analyzing big data because they have a great ability to determine decision-makers' needs. Study (Sanchez, 2019 ) stated There is uncertainty among accountants about how to incorporate big data within their firms or how to determine which steps to take when crafting an effective analytics strategy, and it indicated five main tips to accountants on actions to take when utilizing big data which includes focusing on outliers and unexpected patterns, create visuals that emphasize insights, anticipate initial costs for investment into big data, prioritize cybersecurity, make sure you have the right team from accountants who can analyze the big data you possess. Given the rapid growth of big data, the researcher sensed the importance of the study's subject and the dire need for conducting it. In fact, the application of analyzing big data in accounting is still at an early stage, and there is no study has examined the impact of big data analytics on improving the quality of accounting information.

Big data represents one of the most urgent challenges in the accounting profession, which faces many challenges such as rapid financial and economic changes, financial corruption, globalization, and not familiarity with new developments of information technology. Recently, the topic of the quality of accounting information was of considerable importance owing to the crisis of business organizations negatively affected the user of financial reports. This age is characterized by the abundance of data, but at the same time, accountants and decision-makers face the difficulty of processing this data and then benefiting from it. Hence, the subject of big data analytics and its importance for the accounting profession is one of the most significant topics, which needs further discussion and analytics. The importance of analyzing big data lies in trying to avoid the lack of information contained in the financial reports. The current study explores the importance of analyzing big data in improving the quality of accounting information, positively affecting the quality of financial reports. Accordingly, the study problem revolves around the following question: what is the impact of big data analytics on improving the quality of accounting information?

To achieve the study's objective, the study is divided into four sections: firstly, the theoretical framework of big data and its impact on the accounting profession, secondly, the role of big data analytics in improving the quality of financial reports, thirdly, the study's methodology, fourthly, findings and recommendations.

\section{The Theoretical Framework of Big Data and Its Accounting Profession 2.1 The Concept of Big Data}

There are various definitions of this term. (Gartner, 2018) defined it as: "it is a big, various and fast flow information, that requires using economically feasible and innovative processing 
methods with aim of developing decision- making methods and the automation of processes". According to (ISO, 2017), big data is "a set of data characterized by volume, velocity, diversity, variance, veracity, and validation. It cannot be efficiently processed by using traditional technology". It is defined by (Vasarhelyi, et. al., 2015) as: "an increasing amount of information provided by developments in computing, information technology, and the Internet". The researcher believes that the increase in the amount of data is not a new matter, but the rate of growth of data is unprecedented, and that data analytics is not a new thing, as accountants use analytical procedures such as the analytics of ratios and time series analytics. However, technology and available tools have shifted from focusing on historical data to applying forecasting models and predictive analytics. According to the researcher, big data is "a set of financial and non- financial data, structured and unstructured, obtained from internal and external sources of the organization.

\subsection{Types and Characteristics of Big Data}

Big data is to be divided into; first, structured data which is data stored in database fields. It can be managed, analyzed, and searched by using Structured Query Language (SQL). Second, unstructured data which is data that cannot be easily classified such as images, graphics, video clips, PDF files, presentations, Emails, Tweets, web pages, Facebook posts, chat message. Third, semi- structured data which is a mixture of structured and unstructured data, but it lacks an organized structure such as word processing programs (Rashwan, 2018).

Two studies of (Al-Salmi, 2018 \& O'Leary, 2018) have identified the characteristics of big data, which are: 1) Volume: big data is characterized by more quantities of data than data of traditional methods. 2) Velocity: big data is being generated rapidly more than data of traditional methods so that it flows heavily because of active interaction with the topics of individuals, clients, and beneficiaries. 3) Variety: big data is more diverse than traditional accounting data, as it contains other data such as image, video, audio, and text. 4) Veracity: it refers to the reliability of data where beneficiaries interest in the quality of data. 5) Value: it indicates that data contributes to taking a sound decision in due course.

\subsection{The Importance of Big Data Analytics}

According to studies of (Ace Cloud Hosting Editor, 2020; Rembert, 2020; Georde, et. al., 2018; Appelbaum, et al., 2018; Sun, et al., 2018; Gashi and Saed, 2018, Janssen et. al., 2017; Cao et al., 2015), big data analytics plays a significant role in providing a highly competitive advantage for institutions, creating the value, rationalizing decision- making, contributing to a comprehensive vision of the company, creating future strategic planning, adopting a developed strategy and roadmap for business organizations, improving information quality, real-time access, supporting integrated reporting more effectively, the data that use in reports will be more agile and accurate compared to data sets forecasted in the past, improving risk management, discovering opportunities to reduce costs, increasing companies' profits, providing better services to clients and optimizing customer relationships, increasing opportunities for innovations in developing processes and products, promoting business intelligence, helping in taking future decisions, as well as promoting the efficiency and accuracy of predictive analytics, its ability to illuminate previously unseen insights, predict future outcomes, and automate nonroutine financial tasks, increase the Efficiency of Acquisition. Accordingly, the researcher holds that the importance of big data does not stem from data itself, but from the ability of such data to generate useful visions for business organizations.

\subsection{Big Data Challenges}

Studies (Khvoynitskaya, 2020; Al-Aklabi, 2018; Al-Shoubkeh, 2018; Appelbaum, 2016; Dzuranin and Irina, 2016) show that there are challenges when dealing with big data. These challenges are the volume of increasingly and continuously big data, the enormous growth in 
the amount of data, random search and retrieval of data, data variety, lack of specialists in analyzing big data, difficulties in data storage and processing, and lack of sophisticated automated systems, data security caused by the security skill gap, a lack of education and training opportunities, this gap is growing and will reach 3.5 million cybersecurity positions by 2021, also an evolution of cyberattacks, and Irregular adherence to security standards. The study of (Zieari, 2017) has demonstrated challenges faced by organizations when analyzing big data. The study has divided challenges into three sections: first, data challenges that contain: volume, variety, velocity, veracity, the data quality, the data discovery, relevance and inclusiveness of data, as well as privacy. Second, process challenges that include the difficulty of choosing between similar data, converting data into analytical form, data modeling, understanding outputs, and how to present complex analyses of data. Third, management challenges that contain: data privacy, security, governance, and ethics (Cockcroft \& Mark, 2018).

\subsection{The Effect of Big Data on Accountants' Roles}

Big data significantly affects the roles of accountants, as it provides an opportunity for them to move to strategic roles in business organizations and it helps accountants to convert from decision-makers to business partners. (Greg et al., 2017) has stated that about $94 \%$ of the accounting and auditing jobs will be run automatically. Accountants can create value by acquiring data analytics skills (Bohdan, 2015). The study (Faye, 2016) has emphasized that big data affects the future of companies and the change roles of accountants and financial analysts. According to (Gamagea, 2016), professional accountants and financial analysts need to bridge the gap between information technology and business. (McKinney, et al., 2017) has clarified that candidates for new jobs of accountants, who have technical and statistical skills in managing and analyzing big data, will they become more valuable than their peers and receive the highest salaries. Therefore, accountants should increase their ability to interpret big data to improve the quality of accounting information and add value to business organizations.

Study (Cohn, 2020) indicated that finance and accounting professionals are increasingly implementing big data in their business operations, and many financial officials expect significant changes for 2020 in their business, and accountants will need to develop the skills necessary to keep pace with technology and behavior strategic business partners in their organizations. IMA has renewed the Management Accounting Competencies framework to include more technology and analytical skills, the group also reviewed the Certified Management Accountant exam to add the Technology and Analytics division to CMA candidates. Nowadays, data visualization skills are increasingly important for management accountants and become an essential part of the job for many accountants, that's where there is an important role for management accountants to act as a bridge between data scientists and management.

According to (AACSB A7, 2014), accounting programs should include learning experiences that develop skills integrated information technology into accounting. These educational experiences include skills of data creation, data management, and analytics, data reporting, data security, and storage. In addition, data analytics, information technology skills and knowledge development should be a key component of accounting curricula (Janvrin \& Marcia, 2017). The researcher sees that this standard should be included in curricula with the aim of developing students and professional accountants. There are guidelines for accounting curricula in academic units, including knowledge of the main statistical techniques related to data analytics, the understanding of computer analytics, predictive analytics, and institutions risk assessment.

\subsection{The Impact of Big Data on Accounting}

The accounting industry is rapidly transforming with the economy toward a data-driven market, that relies on analytical skills and precision. 
Big data includes: 1) image and video data: videos contain a worker's productivity tracking video, video of inventory to measure productivity and identify bottlenecks, video of interview through which the management interviews are analyzed to extract content, emotion, and then to provide non-verbal information about business risks and review. These non- verbal components are more important than verbal content where such components create an image of intentions of executive management. 2) Audio data: analyzing audio data can achieve quarterly gains, such as quarterly conference calls, shareholder and board meetings, customer calls, employees' internal phone calls. 3) Textual data: it includes web pages, Facebook and Twitter. This data is useful in supporting marketing, giving an early alarm about product defects, forecasting the volume of sales, and evaluating and improving business performance. Companies extract and merge big data formats from video, images, audio, and text with traditional financial data in order to promote accounting records, improve the quality of financial information, promote transparency, rationalize decision- making and meet stakeholders' demands.

There is an increase in video, image, audio and text data that affects traditional accounting records and information (McKnight, 2015). Big data analytics will affect financial accounting by influencing the collection, recording and management of data, and the preparation of financial statements. Text, video and audio data is linked with traditional data by improving accountants' analytical skills. Additionally, big data affects the fair value of assets and liabilities, as it reduces the estimate of subjective assumptions (Zabihollah \& Jim, 2017).

Big data analytics removes the differences between Generally Accepted Accounting Principles (GAAP) and Financial Accounting Standards Board (FASB). It also helps in moving towards a global accounting system (Warrant et al., 2015). Big data plays an important role in the review process because it provides traditional evidence with enough and reliable information such as using data of the Global Positioning System (GPS) to validate sales and deliveries (Yoon et al., 2015). Also, big data analytics plays a key role in analyzing extrabudgetary elements such as the customer base, the quality of the product, and the reputation of the company. Also, it helps in the emergence of these elements in the actual financial statements by using data extraction algorithms to obtain valuable information (Alles, 2015).

According to (Werner, 2015), big data affects the future of financial reporting and the development of GAAP, where Extensible Business Reporting Language (XBRL), which its origin is Extensible Markup Language (XML), can be used. This language can manage data automatically and has capabilities to convert data into valuable information. The reports prepared on the basis of (XBRL) are an improved electronic version of the financial reports that reduces data processing time, prepares environmentally friendly electronic financial reports, improves the analytics of financial information, publishes reports in different languages, and increase the degree of disclosure at financial institutions with aim of helping investors in obtaining accurate information. Big data analytic will provide real-time reporting in Big firms, even small firms are trying to leverage the benefits of big data in accounting such as Xero companies are providing cloud accounting software to small businesses to help them tap into the possibilities of big data in accounting. (Singh, 2020)

Financial accounting technology facilities managing big data, as modern financial systems have technological capabilities when dealing with unlimited data types and merging traditional data with new data in the new accounting program. This program uses database technology by reading billions of records and disclosing them in a nanosecond. These smart technologies use big data and algorithms to show fraud. The most important of technologies, which will reformulate the accounting profession, are big data, cloud computing, data analytics, artificial intelligence, machine learning, blockchain, new business networks, aI algorithms, and robotic process automation (Simone, S. 2020), cyber confidentiality, electronic payment systems, virtual reality, digital services, and social media. Accountants should acquire new skills and use data analytics tools. Companies should modernize their accounting infrastructure (Sommer, 2015). Therefore, the researcher sees that big data analytics in accounting is very important in 
order to provide information that helps in improving financial information quality, completeness and accuracy of accounting records, evaluation of assets, transparency and completeness of financial reports, fair value accounting, and the development of accounting standards and its effectiveness.

\section{The Role of Big Data Analytics in Improving the Financial Reporting Quality 3.1 The Concept and Tools of Big Data Analytics}

According to (Sun et al., 2018), big data analytics is "the process of collecting, organizing and analyzing big data in order to discover, visualize and display patterns, knowledge, and intelligence, in addition to other information within big data. The study of (Georde et al., 2018) has shown that organizations use analytical tools in the field of marketing, communications, retail trade, and review to discover the opportunities inherent in big data. The study of (Al-Jaid, 2017) has indicated that there are many tools and techniques that are used to analyze data such as Hadoop, Mapreduce, GridGain, HPCC, Storm, Sap Hana, and Cassandra. However, Hadoop is one of the most famous of these tools. It is an open-source program or software platform written in Java language with the aim of storage and processing of data in a distributed manner. For instance, data is to be stored on multiple devices, and then the processing data on these devices is to be distributed to accelerate the result of processing. The study of (Philip, Zhang, 2014) has found solutions to big data storage through cloud computing repositories to convert it into useful information.

\subsection{The Effect of Big Data Analytics on the Quality of Financial Reports}

A study (Siriyama \& Norah, 2017) finds that quality means the set of characteristics that accounting information must have in order to be useful to meet the necessary needs of its users such as understandability, reliability, relevance, comparability and mainly related to information ability to make a difference in the decisions of the users of those reports. The quality of accounting information is defined as the characteristics of accounting information contained in financial statements and reports. These characteristics help in evaluating the level of accounting information quality, decision- making, and forecasting financial failure. Accounting information quality is characterized by understandability, relevance, reliability, comparability.

Studies differed in the methods of measuring the quality of financial reports, as there were two ways to measure: The first trend: Measuring the quality of financial reports through the characteristics of the quality of accounting information, such as relevance, reliability, comparability, understandability. The second trend: measuring the quality of financial reports through the quality of profits by the value of the accrual, or a set of financial indicators. The current study will focus on the first direction.

\subsubsection{Big Data Analytics and Understandability Characteristic}

Big data analytics leads to improving the understanding and analytics the content of information contained in the financial reports, showing unclear information, providing a better image of the company, improving understanding of other information contained in reports such as discussions, phone calls, and videos, improving the understanding of the company's strategic performance, improving the understanding of the company's different operations and then improving the understanding of the performance of the company as a whole, providing valuable information about the understanding and decision- making of the company. A better opinion can be reached by relying on detailed information about the company, leading to a better understanding of the success or failure of the company. The study of (Lattabi, 2018) has indicated that big data represents the future and developed aspects of the information industry 
and the value creation with aim of the development of the economy, promoting growth, rationalizing decision- making, increasing productivity and product quality. The study of (Aldridge, 2019) has confirmed that big data analytics helps in increasing the cognitive content of financial information, particularly when allocating portfolios. Therefore, the researcher believes that big data analytics improves the comprehensibility of accounting information.

\subsubsection{Big Data Analytics and the Relevance Characteristic}

Big data analytics positively affects the facility by improving the prediction of the future profits and risks, improving the prediction of future growth opportunities, improving the prediction of future sales, forecasting financial fraud, early detecting of weaknesses and strengths, improving the evaluative capability of financial reports, and hence improving the evaluation of the performance of the company. The studies of (Singh, 2020; Gepp et al., 2018) has indicated the importance of big data in accounting and auditing, it helps produce better data-driven audits, hence, creating a better experience for auditors, in the tax process, it helps evaluate tax codes, reduce fraud, and monitor budget and tax expenses, and where big data technologies are used in models of predicting turmoil, financial failure, financial fraud, stock markets, and quantitative modeling through the decisions tree, neural networks, and algorithms. The study of (Rezaee et. al, 2018) emphasized the importance of big data analytics for the profession of accounting and auditing, as the management can use big data and time-series analytics in order to predict net income, stock prices, fair value estimates, risk assessment, financial fraud detection. The study has collected net income data of time series for years from 1982 to 1994 with the aim of predicting the net income for years from 1995 to 1997. The financial component has been used in big data (disclosed profits), which is organized and structured data, and merged with nonfinancial and unstructured components such as data of images and governance, social and environmental, and social media with aim of analyzing and transforming them into useful information, have predictive value, feedback value, and timeliness. So, the researcher believes that big data analytics leads to improving the relevance characteristic of accounting information.

\subsubsection{Big Data Analytics and Reliability Characteristic}

Big data analytics leads to the completion of financial reports, improving the prediction of the facility's risks, achieving consensus among stakeholders, and displaying hidden information in financial reports that reduce information asymmetry and then the improvement of financial reports veracity (Al-Htaybat and Larissa, 2017). Big data analytics provides information that makes accounting information verifiable and neutral, has faithful representation, and is reasonably free of errors and bias as it analyzes internal information such as discussions, meetings and phone calls that cannot be shown in traditional methods. Consequently, this increases the credibility of the facility's performance and financial position. Big data provided by the Internet, whether in the form of sound, image, or video, is of great importance to investors in the Egyptian stock market because it is important and useful when making rational decisions, buying or selling shares. The disclosure of companies about non-financial information (videos and images), which is complementary to financial reports, can promote the quality of the investment concept. The study of (Kaya and Destan, 2018) has indicated that big data analytics affects accounting and the accuracy of financial reports.

The study has shown that companies follow the procedures of big data analytics adopted by other companies to maintain and promote their competitive advantages. Financial reports professionals are trying to adapt to challenges of using and mastering new technologies and applications, as well as improving their capabilities and skills in the field of big data analytics. The study of (Griffin \& Arnold, 2015) has concluded that big data analytics is an urgent issue and a real opportunity for accountants and that there is no change in the nature of accounting and financial disclosure, but there is the change in the traditional methods of registration, collection, and analytics of accounting information. 
International Journal of Economics, Business and Accounting Research (IJEBAR)

Peer Reviewed - International Journal

Vol-4, Issue-3, 2020 (IJEBAR)

E-ISSN: 2614-1280 P-ISSN 2622-4771

http://jurnal.stie-aas.ac.id/index.php/IJEBAR

The study also concluded that big data analytics considerably affects the future and accuracy of financial reports and the development of accepted accounting principles, in particular on the disclosure of "off-balance-sheet assets" and fair value accounting. Thus, the researcher holds that big data analytics leads to the improvement of the reliability of accounting information.

\subsubsection{Big data Analytics and Comparability Characteristic}

Big data analytics leads to improves the comparability of the enterprise's sectors, the company's comparison for more than one financial period, and between similar sectors in other facilities through the detailed information provided by big data analytics. The study of (Faye, 2016) has indicated that Halen Crofts, content advisor in Koplan Company, has mentioned that every sector, from the manufacturing sector to retrial and services, each benefit from the opportunity to increase operational efficiencies, assess risks and identify advantages and weaknesses through big data analytics. So, the researcher believes that big data analytics leads to the improvement of the comparability characteristic of accounting information.

Based on the above, big data analytics leads to improving the Qualitative characteristics of accounting information, and hence improving accounting information quality, which reflects positively on the quality of financial reports.

\section{Methodology}

The study aims to identify the attitudes and opinions of academics in Saudi Universities, and also financial analysts, accountants and experts in big data analytics in 2019 through a questionnaire distributed to validate the following hypothesis: "there are statistically significant differences between the study sample on the effect of big data analytics on improving the quality of accounting information in the Saudi environment".

The study population consists of academics, financial analysts, accountants, and big data analysts having experience and awareness. The sample contains 200 items. Correct questionnaires reached 154 with a response rate of $77 \%$, which is an acceptable rate for conducting the statistical analytics. Likert Quintet Scale is used (Completely disagree 5, disagree 4 , neutral 3, agree 2, completely agree 1 ). The researcher has measured the study's variables by using 10 sub-questions. These variables have been summarized as follows: $\mathrm{X}_{1},{ }_{0000}$, $\mathrm{X}_{10 .}$

Table No. (4/1)

Collecting the Study' Questionnaire

\begin{tabular}{|c|c|c|c|c|}
\hline \multirow{2}{*}{ Items } & \multicolumn{3}{|c|}{ Total Questionnaire } & \multirow{2}{*}{$\begin{array}{c}\text { The Response } \\
\text { Percentage }\end{array}$} \\
\cline { 2 - 4 } & Distributed & Received & Refused & $84 \%$ \\
\hline $\begin{array}{c}\text { Academics at Saudi } \\
\text { Universities }\end{array}$ & 50 & 42 & 8 & $70 \%$ \\
\hline $\begin{array}{c}\text { Financial analysts at } \\
\text { Saudi Market }\end{array}$ & 50 & 35 & 15 & $74 \%$ \\
\hline $\begin{array}{c}\text { Accountants at Saudi } \\
\text { bureaus }\end{array}$ & 50 & 37 & 13 & $80 \%$ \\
\hline $\begin{array}{c}\text { Experts in big data } \\
\text { analytics }\end{array}$ & 50 & 40 & 10 & $77 \%$ \\
\hline Total & 200 & 154 & 46 & \\
\hline
\end{tabular}

Source: prepared by the researcher

Table No. (4/2) explores the distribution of the sample according to the experience years and the extent of respondents needs to analyze big data.

Table No. (4/2)

The Distribution of the Study's Sample According to Experience Years and the Extent of Respondents' Needs to Analyze Big Data 
International Journal of Economics, Business and Accounting Research (IJEBAR)

Peer Reviewed - International Journal

Vol-4, Issue-3, 2020 (IJEBAR)

E-ISSN: 2614-1280 P-ISSN 2622-4771

http://jurnal.stie-aas.ac.id/index.php/IJEBAR

\begin{tabular}{|c|c|c|c|c|c|c|c|}
\hline \multirow{2}{*}{ Item } & \multicolumn{4}{c|}{ Experience Years } & \multicolumn{3}{c|}{ The extent of your need to analyze } \\
big data
\end{tabular}

Source: prepared by the researcher according to the result of statistical analytics of respondents. Table No. (4/2) illustrates that the number of 51 by $33.1 \%$ of the total sample are practicing the profession for 10 years or more, and the number of 59 by $38.3 \%$ are practicing the profession for a period ranging between 5-10 years and the number of 44 by $28.6 \%$ are practicing the profession for 5 years or less. As for the extent of respondents' needs to analyze big data, the previous table demonstrates that the number of 70 by $45.5 \%$ of the total respondents need continuously such information, and the number of 50 by $32.5 \%$ need irregularly this information, and the number of 34 by $22 \%$ need rarely such information.

\subsection{The Analytics of the Results of the Statistical Study and Validating Hypotheses 4.1.1 Coefficients of Reliability and Consistency}

The consistency factor is measured by using Cronbach's alpha. Table No. (4/3) shows that the values of the two reliability and consistency coefficients are high. The value of consistency coefficient reached (0.746), and the value of the reliability coefficient reached (0.864). Therefore, it can be said that coefficients are of well- significance, upon which can be relied on in order to generalize the results of the study population.

Table No. (4/3)

Coefficients of Consistency and Reliability Regarding Questionnaire

\begin{tabular}{|c|l|c|c|c|}
\hline Axis & \multicolumn{1}{|c|}{ Statement } & $\begin{array}{c}\text { The } \\
\text { number of } \\
\text { elements }\end{array}$ & $\begin{array}{c}\text { Consistency } \\
\text { coefficient }\end{array}$ & $\begin{array}{c}\text { Reliability } \\
\text { coefficient }\end{array}$ \\
\hline First & $\begin{array}{l}\text { The impact of big data } \\
\text { analytics on characteristics of } \\
\text { accounting information } \\
\text { quality }\end{array}$ & 10 & 0.746 & 0.864 \\
\hline
\end{tabular}

Source: it is prepared by the researcher according to the results of statistical analytics of respondents.

\subsubsection{Testing Normal Distribution: Klamagrove- Simirnov Test}

Table No. (4/4)

The Results Klamagrove- Simirnov's Test on One Sample

\begin{tabular}{|c|c|c|c|c|}
\hline Variables & $\mathrm{N}$ & \multicolumn{2}{|c|}{ Normal Parameters } & $\begin{array}{c}\text { Klamagrove- } \\
\text { Simirnov Z }\end{array}$ \\
\cline { 3 - 4 } & & $\begin{array}{c}\text { Std. } \\
\text { Deviation }\end{array}$ & Mean & \\
\hline $\mathrm{Z}_{1}$ & 154 & 1.15 & 1.84 & 0.925 \\
\hline
\end{tabular}


International Journal of Economics, Business and Accounting Research (IJEBAR)

Peer Reviewed - International Journal

Vol-4, Issue-3, 2020 (IJEBAR)

E-ISSN: 2614-1280 P-ISSN 2622-4771

http://jurnal.stie-aas.ac.id/index.php/IJEBAR

Source: it is prepared by the researcher according to the results of statistical analytics of respondents.

Table No. (4/4) shows that the data distribution was normal, as the test value of the variable $\mathrm{Z1}$ reached (0.925) with a significant level of (0.359), which is greater than the level of significance of $(\alpha>0.05)$. This indicates that the data follow the normal distribution.

\subsubsection{The Arrangement of Variables' Relative Importance}

Table No. (4/5) presents the relative importance of the opinions of respondents on the impact of big data analytics on the characteristics of accounting information quality from respondents' perspectives.

Table No. (4/5)

The Relative Importance of Respondents' Opinions about the Impact of Big Data Analytics on the Characteristics of Accounting Information Quality

\begin{tabular}{|c|c|c|c|c|}
\hline \multirow[t]{2}{*}{ Elements } & \multicolumn{4}{|c|}{ The Relative Importance \% } \\
\hline & Academics & $\begin{array}{l}\text { Financial } \\
\text { analysts }\end{array}$ & Accountings & $\begin{array}{c}\text { Experts in } \\
\text { big data } \\
\text { analytics }\end{array}$ \\
\hline $\begin{array}{l}\text { Big data analytics leads to providing } \\
\text { relevance and objective and valuable } \\
\text { information which helps in decision- } \\
\text { making on the economic unit }\end{array}$ & 85.7 & 77.0 & 84.2 & 78.7 \\
\hline $\begin{array}{l}\text { Big data analytics leads to the } \\
\text { improvement of understanding and } \\
\text { analytics of the content of accounting } \\
\text { information }\end{array}$ & 87.3 & 80.0 & 89.4 & 74.7 \\
\hline $\begin{array}{l}\text { Big data analytics leads to the } \\
\text { improvement of understanding the } \\
\text { annual financial reports by providing } \\
\text { detailed data on the economic unit } \\
\text { through discussions, phone calls and } \\
\text { videos, which increase the reliability } \\
\text { and quality of accounting information }\end{array}$ & 78.9 & 82.3 & 77.5 & 81.1 \\
\hline $\begin{array}{l}\text { Big data analytics leads to the } \\
\text { improvement of understanding the } \\
\text { nature of different operations of the } \\
\text { economic unit and improves } \\
\text { understanding of the strategic } \\
\text { performance of the economic unit as a } \\
\text { whole. }\end{array}$ & 75.3 & 74.1 & 87.2 & 70.9 \\
\hline $\begin{array}{l}\text { Big data analytics leads to the } \\
\text { improvement of predicting future } \\
\text { profits and risks, which increases the } \\
\text { reliability and quality of accounting } \\
\text { information. }\end{array}$ & 71.1 & 93.1 & 77.9 & 88.5 \\
\hline $\begin{array}{l}\text { Big data analytics leads to improving } \\
\text { the opportunities for future growth, and } \\
\text { the improvement of predicting the } \\
\text { future performance of the economic }\end{array}$ & 70.6 & 97.3 & 77.5 & 84.9 \\
\hline
\end{tabular}


International Journal of Economics, Business and Accounting Research (IJEBAR)

Peer Reviewed - International Journal

Vol-4, Issue-3, 2020 (IJEBAR)

E-ISSN: 2614-1280 P-ISSN 2622-4771

http://jurnal.stie-aas.ac.id/index.php/IJEBAR

\begin{tabular}{|c|c|c|c|c|}
\hline units. & & & & \\
\hline $\begin{array}{l}\text { Big data analytics leads to improving } \\
\text { the assessment of the company's } \\
\text { performance, which increase the degree } \\
\text { of confidence in accounting } \\
\text { information. }\end{array}$ & 74.6 & 91.6 & 70.4 & 79.9 \\
\hline $\begin{array}{l}\text { Big data analytics leads to providing } \\
\text { stakeholders with further information, } \\
\text { which improves the quality of } \\
\text { accounting information and then reduce } \\
\text { the asymmetry of information. }\end{array}$ & 81.5 & 88.9 & 71.9 & 69.2 \\
\hline $\begin{array}{l}\text { Big data analytics leads to improving } \\
\text { information comparability among } \\
\text { sectors of the economic unit or between } \\
\text { a specific sector and its counterpart at } \\
\text { the market. }\end{array}$ & 68.7 & 68.6 & 61.7 & 66.7 \\
\hline $\begin{array}{l}\text { Big data analytics leads to knowing the } \\
\text { latest development of the economic } \\
\text { unit, which improves the quality of } \\
\text { accounting information. }\end{array}$ & 66.1 & 63.9 & 68.9 & 67.1 \\
\hline
\end{tabular}

Source: it is prepared by the researcher according to the results of statistical analytics respondents' answers

The previous table illustrates that the most important elements according to the standard of relative importance are the following:

\section{Academics' Opinion}

- Big data analytics improves understanding and analyzing the content of accounting information.

- It provides relevance, objective, and valuable information, which helps in the economic unit's decision- making.

- It provides further information to stakeholders, which improves the quality of accounting information, and then reduces the asymmetry of information.

- It improves understanding the annual financial reports by providing detailed data on the economic unit through discussions, phone calls and videos, which increase the reliability and quality of accounting information.

- It improves understanding the nature of different operations of the economic unit and improves understanding the strategic performance of the economic unit as a whole.

\section{Financial Analysts' Opinion}

- Big data analytics improves the opportunities for future growth and improves in predicting the future performance of the economic unit.

- It improves predicting future profits and risks, which increase the reliability and quality of accounting information.

- It improves in predicting the evaluation of the company's performance, which increases the degree of confidence in accounting information.

- It provides stakeholders with further information, leading to the improvement of accounting information quality and then reduces the asymmetry of information.

- It improves understanding the annual financial reports by providing detailed information on the economic unit through discussions, phone calls and videos, which increases the reliability and quality of accounting information. 


\section{Accountants' Opinion}

- Big data analytics improves understanding and analyzing the content of accounting information.

- It improves understanding the nature of the different operations of the economic unit and improves understanding the strategic performance of the economic unit as a whole.

- In leads to providing valuable, objective, and relevant information, which helps the economic unit in decisions- making.

- It improves predicting future profits and risks, which increases the reliability and quality of accounting information.

- It improves understanding the annual financial reports by providing detailed data on the economic unit through discussions, phone calls and videos, which increases the reliability of accounting information quality.

\section{Big Data Analytics Experts' Opinion}

- It leads to the improvement of predicting future profits and risks, which increase the reliability and quality of accounting information.

- It leads to the improvement of future growth opportunities and improves in predicting the future performance of economic units.

- It improves understanding the annual financial reports by providing detailed data on the economic unit through discussions, phone calls and videos, which increase the reliability and quality of accounting information.

- It improves the assessment of the company, which increases the degree of confidence in accounting information.

- It provides valuable, objective, and relevant information, which helps in the economic unit's decisions- making.

Accordingly, big data analytics affects the characteristics of accounting information, which reflects on the quality of accounting information, leading to the acceptance of the study's hypothesis.

\subsubsection{One Sample T- Test}

Table No. (4/6)

The Results of Using T-Test for Comparing Between Collective Question and the General Mean of Answers

\begin{tabular}{|c|c|c|c|c|c|}
\hline Variable & $\begin{array}{c}\text { Calculated } \\
\text { Value of T }\end{array}$ & $\begin{array}{c}\text { Confidence } \\
\text { Coefficient }\end{array}$ & $\begin{array}{c}\text { Mean } \\
\text { Difference }\end{array}$ & $\begin{array}{c}\text { A Minimum } \\
\text { of Difference }\end{array}$ & $\begin{array}{c}\text { A Maximum } \\
\text { of Difference }\end{array}$ \\
\hline $\mathrm{Z}_{1}$ & $828.58-$ & 0.000 & $28.09-$ & $28.18-$ & $27.99-$ \\
\hline
\end{tabular}

Source: it is prepared by the researcher according to the results of statistical analytics of respondents.

** The confidence coefficient is $99 \%$.

The table (4/6) shows that the calculated value of $\mathrm{T}$ is negative. This indicates that respondents' answers tend to accept at a very high confidence coefficient amounted to $99 \%$. It is noted that the mean difference is negative, and its value is 28.09 . Consequently, the mean difference is less than the general mean by this amount, and this happened only by accident. The study also illustrates that the difference minimum between the answers mean and the general mean is 28.18 , and the maximum difference is -27.99 .

Table (4/7)

The Results of Using T-Test of the General Mean and Standard Deviation and the Mean of Standard Deviation of Variable $Z_{1}$ 
International Journal of Economics, Business and Accounting Research (IJEBAR)

Peer Reviewed - International Journal

Vol-4, Issue-3, 2020 (IJEBAR)

E-ISSN: 2614-1280 P-ISSN 2622-4771

http://jurnal.stie-aas.ac.id/index.php/IJEBAR

\begin{tabular}{|c|c|c|c|c|}
\hline Variable & $\begin{array}{c}\text { The Number } \\
\text { of Variables }\end{array}$ & Mean & $\begin{array}{c}\text { Standard } \\
\text { Deviation }\end{array}$ & $\begin{array}{c}\text { Standard Error } \\
\text { Mean }\end{array}$ \\
\hline $\mathrm{Z}_{1}$ & 10 & 1.91 & 0.421 & 0.034 \\
\hline
\end{tabular}

Source: it is prepared by the researcher according to the results of statistical analytics of respondents' answers.

** The confidence coefficient is $99 \%$.

The previous table's results (4/7) show that the acceptance degrees' general mean of the study sample's variables has reached (1.91) with standard deviation estimated at (0.421). This means that the degree of acceptance is very high among the study sample for all the proposed variables, and this leads to the acceptance of the study's hypothesis.

\section{Findings and recommendations}

Business organizations achieve many advantages when analyzing big data. The most important of these advantages are: contributing to giving a comprehensive view of the economic unit, the development of the economic unit's strategy and business model, achieving a high competitive advantage for institutions, improving the quality of accounting information, providing appropriate information helping in rationalization of decisions within the economic unit, defining performance at past and the source of future information. On the other hand, big data analytics faces several challenges, the most important of which are: lack of personnel specialized in big data analytics, the high costs of employing experienced professionals, the velocity of big data flow affecting the rationalization of decision- making, the difficulty in transferring, storing and processing big data, the difficulty in presenting analyses related to big data. The study has concluded that big data analytics improves the quality of accounting information, as it clearly affects the qualitative characteristics of accounting information, positively affecting the quality of financial reports, this means accepting the study hypothesis "There are statistically significant differences between the study sample on the effect of big data analytics on improving the quality of accounting information in the Saudi environment".

The researcher recommends the necessity of teaching big data and business analyses in accounting education curricula at universities to promote students' knowledge. The researcher also recommends holding workshops and training courses for researchers and academics to know the importance of analyzing big data and how to process, store, manage and use the analyzed data in the financial and accounting field. In conclusion, this research is an open intellectual invitation for conducting further applied and scientific research in the field of big data and its impact on the sustainability of accounting and the development of accounting standards.

\section{References:}

AACSB International. 2014. AACSB International Accounting Accreditation Standard A7: Information Technology Skills and Knowledge for Accounting Graduates: An Interpretation. Tampa, Florida, September 2014.

Ace Cloud Hosting Editor. 2020. How Big Data Is Impacting Accounting Firms in 2020. available at: https://www.acecloudhosting.com/blog/how-big-data-impacting-accountingfirms.

Al-Aklabi, A. b. 2017. Converting Big Data into Added Value. King Fahd National Library Magazine, 23 (2): 1-24.

Al-Aklabi, A. b. 2018. The Importance of Big Data Analytics in Decision Making at King Saud University. The 24th Annual Conference of the Specialized Libraries Association. Arab Gulf Branch, Muscat 6-8 March, 1-15.

Aldridge, I. 2019. Big Data in Portfolio Allocation - A New Approach to Successful Portfolio Optimization. Journal of Financial Data Science, January. 
International Journal of Economics, Business and Accounting Research (IJEBAR)

Peer Reviewed - International Journal

Vol-4, Issue-3, 2020 (IJEBAR)

E-ISSN: 2614-1280 P-ISSN 2622-4771

http://jurnal.stie-aas.ac.id/index.php/IJEBAR

Al-Htaybat, K. and L. V. Alhtaybat. 2017. Big Data and Corporate Reporting: Impacts and Paradoxes", Accounting. Auditing \& Accountability Journal, 30 (4): 850-873.

Al-Jaid, A. 2017. Big Data Analytics and Improvement of Education. available at https://www.new-educ.com.

Alles, M. G. 2015. Drivers of the use and facilitators and obstacles of the evolution of big data by the audit profession. Accounting Horizons, 29 (2): 439-449.

Al-Salmi, J. b. 2018. Big Data and its Role in Supporting Decision Making and Strategic Planning: A Classroom Study. The 24th Annual Conference of the Specialized Libraries Association. Arab Gulf Branch, Muscat 6-8 March, 1-8.

Al-Shoubkeh, Y. A. 2018. Awareness of the concept of big data for academic libraries employees: a case study for the University of Jordan Library. The 24th Annual Conference of the Specialized Libraries Association. Arab Gulf Branch., Muscat 6-8 March, 1-28.

Appelbaum, D. 2016. Securing Big Data Provenance for Auditors: The Big Data Provenance Black Box as Reliable Evidence. Journal of Emerging Technologies in Accounting, 13 (1): 17-36.

Appelbaum. D., M. A. Vasarhely, A. Kogan. 2018. Analytical procedures in external auditing: A comprehensive literature survey and framework for external audit analytics. Journal of Accounting Literature 40: 83-101.

Bohdan, S. 2015. How do Organizations Prepare and Clean Big Data to Achieve Better Data Governance?. Capella University. ProQuest Dissertations Publishing 3682586.

Cao, M., R. Chychyla and T. Stewart. 2015. Big Data Analytics in Financial Statement Audits. Accounting Horizons, 29 (2): 423-429.

Cockcroft, S. and M. Russell. 2018. Big Data Opportunities for Accounting and Finance Practice and Research. CPA Journal, 28 (2): 149-301.

Cohn, M. 2020. Accountants to rely more on big data in 2020. available at:https://www.accountingtoday.com/news/accountants-to-rely-more-on-big-data-in-2020

Coyne, E. M., J. G. Coyne and K. B. Walker. 2018. Big Data information governance by accountants. International Journal of Accounting \& Information Management, 26 (1): 153-170.

Dzuranin, A. and I. Malaescu. 2016. The Current State and Future Direction of IT Audit: Challenges and Opportunities. Journal of Information Systems, 30 (1): 7-20.

Faye, C. 2016. Big Data: Its Power and Perils, The Big Data Effect. available at: https://www.accaglobal.com.

Gamagea, P. 2016. Big Data: are accounting educators ready?. Accounting and Management Information Systems, 15 (3): 588-604.

Gartner Inc. 2018. Big Data. copy available at: https://www.gartner.com.

Gashi, K. and S. Al-Awadi. 2018. Big Data and its Impact on Decision Making. Journal of Economics and Applied Statistics, 14 (2): 150-165.

Georde M. S. 2018. Big Data Analytics and the Social Relevance of Auditing: An Exploratory Study. A thesis submitted to The University of Manchester for the degree of Doctor of Philosophy. the Faculty of Humanities, Alliance Manchester Business School.

Georde M. S., A. Samsonova and S. Turley. 2018. Big Data and changes in Audit Technology: Contemplating a Research Agenda. Accounting and Business Research, 1-26.

Gepp, A., M. K. Linnenluecke, T. J.O'Neill and T. Smith. 2018. Big data techniques in auditing research and practice: Current trends and future opportunities 40: 102-115 available at: https://ssrn.com/abstract=2930767

Greg, R., A. Stapleton, T. Stratopoulos and C. Wong. 2017. Big Data Analytics: Opportunity or Threat for the Accounting Profession? available at SSRN: https://ssrn.com/abstract=2813817:1-40. 
International Journal of Economics, Business and Accounting Research (IJEBAR)

Peer Reviewed - International Journal

Vol-4, Issue-3, 2020 (IJEBAR)

E-ISSN: 2614-1280 P-ISSN 2622-4771

http://jurnal.stie-aas.ac.id/index.php/IJEBAR

Griffin, P. A. and A. M. Wright. 2015. Commentaries on Big Data's Importance for Accounting and Auditing. Accounting Horizons, 29 (2).

International Organization for Standardization (ISO/IEC). 2017. Big Data. available at: Web www.iso.org.

Janssen, M., H. V. D. Voort and A. Wahyudi. 2017. Factors influencing big data decisionmaking quality. Journal of Business Research, 70: 338-345.

Janvrin, D. J. and M. Weidenmier. 2017. Big Data": A new twist to accounting. Journal of Accounting Education, 38: 3-8.

Kaya, I. and D. H. Akbulut. 2018. Big Data Analytics in Financial Reporting and Accounting. Press Academia, Procedia (45): 256-259.

Khvoynitskaya, S. 2020. The future of big data: 5 predictions from experts for 2020-2025. available at: https://www.itransition.com/blog/the-future-of-big-data.

Krahel, J. P. and W. R. Titera. 2015. Consequences of Big Data and Formalization on Accounting and Auditing Standards. Accounting Horizons, 29 (2): $409-422$.

Lattabi, M. 2018. Big Data and the Information Industry. Al-Hikma Journal for Media and Communication Studies. University of Algeria 6 (4): 56-84.

McKinney, E., C. Yoos and K. Snead. 2017. The need for 'skeptical' accountants in the era of Big Data. Journal of Accounting Education, 38: 63-80.

McKnight, C. 2015. Preliminary Investingation of Big Data and Implications for Accounting Curricula. available at: https://unitec.researchbank.ac.nz: 1-11.

O’Leary, D. E. 2018. Big Data and Knowledge Management with Applications in Accounting and Auditing: The Case of Watson. electronic copy available at: SSRN: https://ssrn.com/abstract=3203842, 9: 1-24.

Philip C. and Zhang C. 2014. Data-Intensive Applications, Challenges, Techniques and Technologies: A survey on Big Data. Information Sciences Journal, 275: 314-347.

Rashwan, A. M. 2018. The Role of Big Data Analytics in Rationalizing Financial and Administrative Decision Making in Palestinian Universities - Field Study. Journal of Economic and Financial Studies, Faculty of Economic, Commercial and Management Sciences 11 (1): 22-41.

Rembert, L. 2020. How Accounting Teams Can Leverage Big Data. available at: https://tdwi.org/articles/2020/03/03/adv-all-how-accounting-teams-can-leverage-bigdata.aspx

Rezaee, Z., A. Dorestani and S. Aliabadi. 2018. Application of Time Series Analyses in Big Data: Practical, Research, and Education Implications. American Accounting Association, available at: https://ssrn.com/abstract=3148726: 1-37.

Sanchez, M. 2019. 5 Ways Accountants Can Effectively Utilize Big Data. available at: https://www.accountingweb.com.

Simone, S. 2020. 10 Predictions for Big Data in 2020. available at: http://www.dbta.com/Editorial/News-Flashes/10-Predictions-for-Big-Data-in-2020135890.aspx.

Singh, H. 2020. Effect of Big Data on Accounting and Financial Services. available at: https://www.softwaresuggest.com/blog/effect-of-big-data-on-accounting.

Siriyama K. H. and N. Albarqi. 2017. Financial Reporting Quality: A Literature Review. International Journal of Business Management and Commerce, 2 (2):1-15.

Sommer, B. 2015. When Change Isn't an Option but a Mandate: What Big Data Is Doing to Accounting? available at: https://www.IFAC.org: 1-4.

Sun, Z., L. L. Sun and K. Strang. 2018. Big Data Analytics Services for Enhancing Business Intelligence. Journal of Computer Information Systems, 58 (2): 162-169.

Vasarhelyi, M. A., A. Kogan and B. M. Tuttle. 2015. Big data in accounting: an overview. Accounting Horizons, 29 (2): 381-396. 
International Journal of Economics, Business and Accounting Research (IJEBAR)

Peer Reviewed - International Journal

Vol-4, Issue-3, 2020 (IJEBAR)

E-ISSN: 2614-1280 P-ISSN 2622-4771

http://jurnal.stie-aas.ac.id/index.php/IJEBAR

Warren, D., K. Moffitt, and P. Byrnes. 2015. How accounting records will change with Big Data. Accounting Horizons, 29 (2): doi:10.2308/acch-51069.

Werner, J. R. 2015. How Big Data Will Likely Change the World of Accounting. available at: https://blog.frankfurt-school.de/big-data-will-likely-change-world-accounting:1-5.

Yoon, K., L. Hoogduin and L. Zhang. 2015. Big Data as Complementary Audit Evidence. Accounting Horizons, 29 (2): 431-438.

Zabihollah, R. and J. Wang. 2017. Big Data, Big Impact on Accounting. APLUS, 42-45.

Zicari. 2017. Big Data: Challenges and Opportunities. electronic copy available at: http://odbms.org, 5th December 2017. 